Mercator, Fortaleza, v. 16, e16006, 2017.

DOI: https://doi.org/10.4215/rm2017.e16006

ISSN: 1984-2201

Copyright @ 2002, Universidade Federal do Ceará

\title{
BEYOND BELIEFS ABOUT FOOD AND THE FLAVORS OF NATURE
}

\author{
ALMEIDA, Maria Geralda de ${ }^{\text {* }}$
}

(a) Phd in Geography. Full Professor Federal University of Goiás (UFG). http://lattes.cnpq.br/4465452999284335

\section{(*) CORRESPONDING AUTHOR}

Address: UFG/IESA - Campus Universitário Samambaia, CEP: 74000-970, Goiania (GO), Brasil. Tel: (+55 62) 35211170 E-mail:mgdealmeida@gmail.com

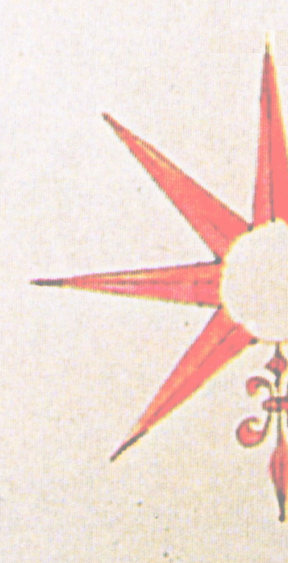

\begin{abstract}
This is a preliminary discussion that seeks to highlight the meanings of flavors and foods to create relationships between mankind and nature, understanding that cultural reasons attribute meanings to the flavors of foods. Anthropological references are the theoretical basis for a discussion of the possibilities of the existence of an alimentary identity. Furthermore, food is already one aspect of identity. In addition we discuss what conditions the use of nature and the rejection of the consumption of certain products from nature as food. Our concern is to present the characteristics of a geography of food and flavors. The research included the work of various authors from the fields of Geography, History, Anthropology and Social Sciences.
\end{abstract}

Keywords: Meanings of foods; Relationships between food and nature; Spatialization of flavors.

\section{RESUMO/ RESUMEN}

\author{
PARA ALÉM DAS CRENÇAS SOBRE ALIMENTOS , COMIDAS E SABORES DA NATUREZA
}

Consiste em discussão preliminar que procura evidenciar os significados dos sabores e dos alimentos para se criar relações entre os homens e a natureza, entendendo que as razões culturais atribuem os significados dos sabores aos alimentos. As referências antropológicas constituem a base teórica para se discutir as possibilidades de existência de uma identidade alimentar. Além disso, a comida já é um aspecto da identidade. Discute-se, ainda, o que condiciona o uso da natureza, o rechaço ao consumo de certos produtos da natureza como alimento. Preocupa-se em apresentar e os elementos que caracterizam uma geografia dos alimentos e dos sabores. Foram pesquisados autores diversos da Geografia, História, Antropologia e Ciências Sociais.

Palavras-chave: Significados de alimentos; Relações comida e natureza; Espacialização de sabores.

\section{MÁS ALLÁ DE LAS CREENCIAS SOBRE ALIMENTACIÓN Y SABORES DE LA NATURALEZA}

Se trata de una discusión preliminar que busca los significados de los alimentos de acuerdo con algunos aspectos cualitativos, y botánicos. Se procura evidenciar el significado de los sabores y alimentos para crear relaciones entre los hombres y la naturaleza entendiendo cuales son las razones culturales que atribuyen significados y preferencias a determinados sabores y alimentos. Las referencias antropológicas constituyen la base teórica para discutir las posibilidades de existencia de una identidad alimentar. Además la comida es un aspecto de la identidad. Se discute aún, el condicionamiento al uso de la naturaleza, el rechazo a la utilización de ciertos productos como alimentos y los elementos que caracterizan una Geografía de alimentos y sabores. Se utilizan diversos autores de la Geografía, Historia, Antropología y de las Ciencias Sociales.

Palabras clave: Significado de los alimentos; Relación comida-naturaleza; Espacialización de sabores. 


\section{INTRODUCTION}

Food has meaning beyond nourishment. Referring to food, Levi-Strauss (2004/1964) went further to say that "if it's good to think about, then it's good to eat" that is, thinking about what you eat, what food says, what it communicates and what is communicated through it. In fact, there is a close relationship between what is culturally elected as food and what is grown and consumed by different peoples. Ducrot (2000) shares this idea pointing out that the complexity of our culture requires a study of eating as a revealing expression of a culture. Ultimately, the analysis of the culture of eating seeks to understand society and, in short, ways of life.

This issue has already motivated anthropologists, historians, sociologists and geographers who, in various aspects, have sought to address the possibilities of reflecting on food. In fact, this seduction by the theme is cited by Claval (1995, p.255), for whom "food, eating and drinking: there is no field more fascinating for the geographer to analyze." In the brief discussion herein, the emphasis is on interpreting how cultural reasons constitute food identities and how these reasons are associated to the meanings of flavors and foods.

My land is the north of Minas Gerais - the region of the Gerais, with large plateaus, hot and dry weather, irregular and poor rainfall, predominantly typical openCerrado vegetation, with shrubs, herbaceous plants, scarce trees and, in the more arid areas, rare cacti in stony soils. Similar climatic-botanical aspects reveal an ecotone, transitioning between the cerrado and the caatinga; the savanna predominates in the vast gerais. However, the north of Minas Gerais, like the whole of Central Brazil and areas dominated by the Cerrado biome is home to the plant species Caryocar brasilensis which is exceptional even for its name that identifies it as genuinely Brazilian: the pequi. The fruit has a bright yellow pulp, unusual for its generous intense scent and flesh hiding under a layer of treacherous thorns for the person who bites it hard.

Monica Abdala Keys (1997, p.11), writing about the culture of Minas Gerais, its cuisine and the construction of the image of its people, highlights the presence of the pequi in the north of Minas Gerais and refers to pequi being eaten mixed with other foods, "which resulted in rice with pequi and sun-dried beef, a typical dish of the north of Minas." The same is the case for Goiás, where the pequi is served daily in meals at typical restaurants; however, when discussing the eating habits of Goiás Barbosa (2008)does not make any reference to this fruit.

According to Abdala the pequi was known to indigenous people. Indeed, a few years prior to Abdala, Vera P. Coelho (1991-1992) carried out an anthropological study of a traditional celebration, the feast of the pequi held by the Waurá Indians in Tocantins. Eaten bountifully during the week-long party, the preparation and consumption of pequi was varied, since these Indians knew about more than 20 varieties of the fruit. She describes the ways of preparing it, both raw and cooked, however, for the researcher the most surprising thing was the smell of the fruit, which was "extremely cloying".

Indeed, the pequi has a particular dense smell that runs through the equally strong flavor, impregnating its partners: rice, flour, beans, chicken and also alcohol when pequi is used as a liquor. This is the taste of the north of Minas Gerais, coming from a product of the Cerrado.

The reference to the north of Minas emphasizes that a number of gustatory indicators affirm a food identity, the memory of a flavor that strongly defines the cuisine of a given territory: palm oil (Elaeis guineensis) in Bahia; açaí (Euterpe oleracea) in Amazonia; bergamon (Citrus bergamia) in Rio Grande do Sul; and pequi (Caryocar brasiliense) in Central Brazil, to name a few.

This food identity is strongly associated with an element of nature; in contemporary times it appears diluted in different territories although the globalization process tends to fray such identity ties. But undoubtedly it still confers a territoriality to food. It can even be said that with territoriality there is a growing trend towards strengthening cultural diversities. These, together with globalization, favor the current eating of "fragments of local cultures," according to De Certeau; Giard; Mayol (1997, p.243). 
Next there is a short discussion of the theoretical contribution, the subjective and biological layers of food to get to the heart of the matter: how to have analytical procedures for a geography of food and flavors? What perceptions affect the use of nature and the rejection of the use of some of its products as food?

\section{A BRIEF THEORETICAL FRAMEWORK}

The act of feeding oneself carries with it a complexity resulting not only from the interrelationship between oneself, man and nature, but of all the different ramifications that it entails, including the difference between feeding oneself and eating, as one can eat without necessarily feeding oneself. This complexity led numerous fields to become interested in the theme. Thus, it can be analyzed using different approaches: medical-health, political, economic, nutritional, geographical, anthropological, historical and psychological due to eating disorders (obesity, bulimia, anorexia).

Progressively, Geography has taken an interest in the subject, seeking the intersections between the social, ecological and cultural, since the human groups that produce and eat food are diverse cultural groups due to their ways of life, their customs and their techniques. Jean-Robert Pitte's $(1986,1991)$ contribution is noteworthy for his two books dealing with food. The first, his doctoral thesis, studies chestnuts, marmalades and marron-glacé. The second makes a thorough analysis of the geography and the history of French cuisine; both use the approach of Cultural Geography.

In addition to Geography, key contributions from related sciences build reflections and methodological definitions. Goody (1982) identifies three methodological approaches, namely: functionalist, structuralist and cultural, each with interpretive features and explanatory models. However, there is a difficulty with classifying the current studies as a single approach, given the explanatory hybridization adopted by scholars. It is not our intention to deepen the discussion as this is not the main objective of this work. By pointing out some contributions we hope to arouse interest in future insights.

According to Hernández and Arnaiz (2005), anthropologists are our main references for this discussion and in the case of the structuralist approach Lévi-Strauss and Barthes are eminent. Roughly speaking, one can say that structuralists examine the significant and aesthetic aspects of nutrition and food. While functionalists examine the food, structuralists examine the cuisine, understood as a set of culturally encoded signs and symbols and as a language capable of being socially interpreted.

Lévi-Strauss' (2004/1964) epigraph, “if it's good to think about its good to eat" reflects both culturism and structuralism. He maintains that food is good to think about and, therefore, good to eat, to the extent that foods must first be considered edible by our mind and accepted for their social meanings before being digested by the body. First, we consider it and if it is fit for our spirit, we eat it. Levi-Strauss says that like language, cooking is a universal activity present in every human society and is configured by a system of culinary traits that contrast and relate to each other. In the years 1961, 1975 and 1980, Barthes, quoted by Hernández and Arnaiz (2005), argued that food, particularly cooked food, constituted a communication system, a protocol of images and customs that manifest a social structure and symbolized social relations.

In Brazil, the anthropologist Carlos Rodrigues Brandão had a similar approach to that proposed by the two aforementioned authors. His study was based mainly on the meaning of food and the binary application proposed by Levi-Strauss to interpret and explain food as cold $\mathrm{x}$ hot, strong $\mathrm{x}$ weak and inflammatory $\mathrm{x}$ non-inflammatory, which will be discussed below.

Sahlins (1988) based himself on "cultural reason" to discuss the food preferences of Americans and their relationship with domestic animals. His culturist orientation led him to analyze the categorical distinctions regarding the edibility of the horse, dog, pig and ox. He sought to confirm that American society's productive relationship is organized by specific values as to what is edible or not; these are qualitative and do not have economic, biological and ecological advantages. For 
Sahlins, exploring the surroundings and the style of relationship with the landscape depends on a food model that includes a central component of meat associated with peripheral ingredients of carbohydrates and vegetables. Meat implies a concept of energy that evokes the masculine pole of a sexual code of food and probably goes back to the Indo-European identification of cattle with virility.

This discussion is very close to Levi-Strauss' ideas, according to which people first think about foods and once they have classified them according to their mental and cultural code, they eat them. It is noteworthy that for these authors aversions to certain foods are cultural in nature.

The main criticisms of studies based on structuralism and culturism concern the priority of the analysis of the descriptive and structural elements of food. They also mention that excessive importance is attributed to cultural reason and, to a lesser extent, biological, historical and ecological phenomena. In doing so they neglect the political and socioeconomic context in which food is produced, prepared and consumed. The same applies to the spatial and temporal evolution.

These two theoretical and methodological contributions were very important from the 1960s to the 1980s. In the 1990s, under the influence of the postmodernist trend, attention to language and particularly its role in the construction of discursiveness and identity attracted the interest of scholars once more. The theme of feeding / food and its relationship with the surroundings, power or domination are studied from the perspective of a more materialistic view of the social. Cultural materialism gained ground seeking to clarify the cultural enigmas related to alimentary preferences and aversions. Ecological studies evolved to show the relationship between culture and nature and studies of ethnoecology and developmentalism increased. Scholars favored investigating the development of food systems for an analysis of globalization and ecological crisis amenable to an understanding of food systems. Contemporaneously, schools such as post-structuralism, constructivism and cultural materialism are basing their studies on this topic in various sciences. However, as it is not the purpose of this study to make a deeper study of the theories above; we hope that this brief overview will awaken the interest of other geographers.

Geographers need to inform themselves about these ideas and prepare a contribution to the dialogue with other sciences. We are referring particularly to those who are interested in diversity and cultural differences manifested through the society-nature relationship to position themselves in a geography of food and food products. It is the geographer Claval (2012) who argues that the ecological relationships of men with their environment are expressed directly in food consumption. This article aims to examine how nature becomes food and therefore calls upon the approach of cultural geography in postmodernism to add some challenges to scholars of this topic.

\section{FLAVORS AND DISTINCTIONS BETWEEN FOOD AND FOODSTUFFS}

In the 1950s, Josué de Castro (1976) wrote about the alimentary areas in Brazil, stating that the Brazilian diet had precarious nutritional qualities, with incomplete and inharmonious dietary patterns. His investigations led him to conclude that such a deficient diet was primarily a product of sociocultural factors rather than geographical factors.

However, he assigns responsibility for poor eating habits to the socioeconomic structure. In his view, the Portuguese traditionally had a good, balanced diet, which unfortunately was not maintained in Brazil. Firstly, this was due to the absence of wheat of a good nutritional standard and later because the Portuguese prioritized the monoculture of sugar and gold exploration and abandoned farming and food standards.

In the same work Castro states that the indigenous people contributed little to the alimentary organization of the colonizers. Their basic contributions were limited to cassava and maize, low in protein and cultivated with traditional techniques. 
On the other hand, he points out that the blacks brought a good African agricultural tradition with them and contributed to food resources not becoming more restricted in the colony of Brazil. Moreover, Africans were important for introducing the alimentary habits from their continent, like palm oil or dendê and pepper to the common diet.

Castro believes that these cultural currents and the desire for economic gains with monoculture and the latifundia defined a particularly characteristic poor diet until the first half of the twentieth century.

Subsequently this profile changed gradually, as migratory flows from several European countries and Japan influenced the Brazilian food patterns, particularly in the Centre and South of the country. The evolution of transport, the increase in purchases over the Internet and movement of goods, in addition to the ease of access to food, allow the purchase of food produced in other climate zones, imported food and even domestic production resulting from high technology, irrigation, chemical products, and the intensive production of crops and factory farming of livestock etc. Currently, as well as being concerned with the nutritional value of food, discussions have also turned back to the meaning and significance of eating and food.

Da Matta (2000) emphasizes that food, with its symbolic possibilities, allows for an important mediation between the head and the stomach, between body and soul. There is a balance and synthesis between the eye and the stomach, which makes it possible to simultaneously operate a number of cultural codes that normally distinguish salty from sweet and bitter; tasty from disgusting, and hot from cold. Barrow (1981) deepened this discussion and drew up a typology based on Levi-Strauss $(2004 / 1964)$ in which the beliefs and customs of the people of the hinterland of Central Brazil defined hot and cold food, as shown in Table 1. For this author, hot is not specifically a reference to the food's temperature. It is believed that this classification of food as hot and cold has a relationship with their capacity of being deemed offensive to the digestive tract, liver and stomach.

The code of odors permits food that smells good and is healthy and wholesome to be distinguished from other foods. The visual code makes us eat or not eat some foods with the eyes or reject it due to its appearance.

Table 1 - The heat or coldness of foods

\begin{tabular}{|c|c|c|c|}
\hline TOO HOT & HOT & NEITHER COLD / NOR HOT & COLD \\
\hline \multirow{2}{*}{ Pork } & Beans & Beef & Watermelon \\
\hline \multirow{2}{*}{ Pequi } & Pumpkin & Domestic Fowl Meat & Lime \\
\cline { 2 - 4 } & Eggs & Rice & Tomato \\
\hline \multirow{2}{*}{ Mango } & \multirow{2}{*}{ Cabbage } & Maize & Vegetables in general \\
\cline { 2 - 4 } & & Small Potato & Cassava \\
\hline
\end{tabular}

Source: Adapted from Brandão, 1981, p.117

In this sense, it is understood that when discussing taste, it is necessary to consider its intertwining with food, since there is a mediation between food and flavor. Foods generate, produce and elaborate flavors, and thus, henceforth we will adopt the term food, to account for flavor from its matrix. It is worth noting that Da Matta (2000, p.55) conceives food as "all that is ingested to keep a person alive." However, between diet and food, it is the latter that is valued by man for cultural reasons as it "is everything that is eaten with pleasure, according to the most sacred rules of communion and commensality" (idem). Therefore, the meaning of food involves senses, meanings, perceptions and beliefs.

For this author, food is not only an alimentary substance; it is also a manner, a style and a way of eating. Food indicates both a universal operation - the act of feeding oneself - and defines and sets personal and group identities, regional and national styles of being, doing and living. 
Eating is, above all, to enter into social relationships and results from a relational cuisine. In the case of Brazil, the author also comments on our way of eating, enjoying a large, bountiful, happy table, present at Sunday lunch, dinner parties, birthdays and weddings, gathering together family and friends. It is a time that brings together freedom, respect and satisfaction. Through the usual food, individuals commune with each other in a festive act, eliminating oppositions and conflicts. With food, we celebrate our relationships more than our individuality. Thus, we relate intensely to celebrations with food and we connect it with friends, pleasure and the satisfaction of sharing the flavors of food.

Different societies assign varied uses to food, as already mentioned here (Figure 1). It is noteworthy that few societies allude to nutritional reasons.

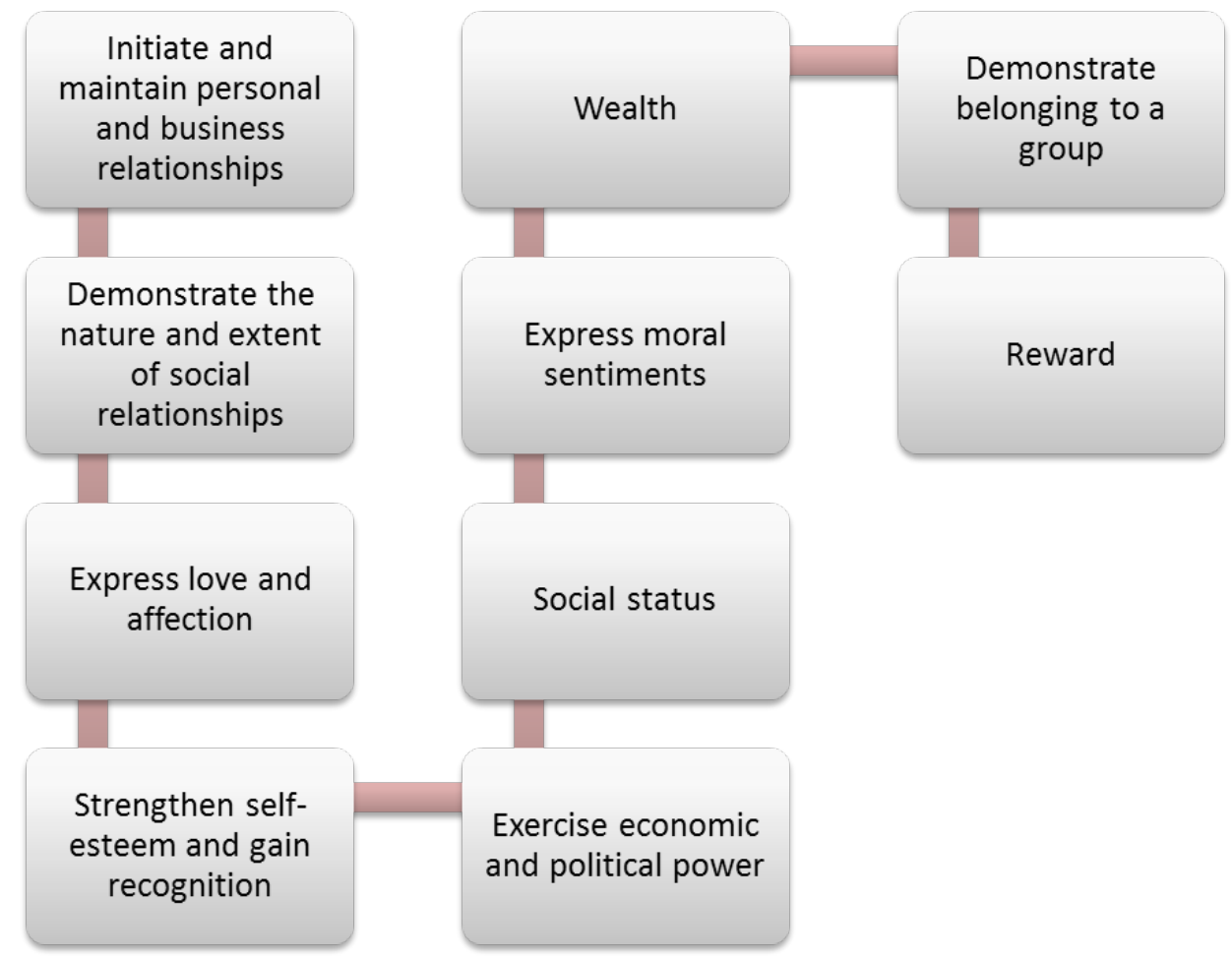

Figure 1 - Sociocultural functions of food

Source: Adapted from Bass, Wakefield y Kolasa, 1979 cited by Hernández and Arnaiz (2005)

\section{VARIOUS FLAVORS: SUGARS AND PEPPERS}

According to Hernández and Arnáiz (2005), one of the biological conditioners of alimentation that played an important role throughout the evolution of the species, as well as contributing to its survival, was the ability of the tongue to detect bitterness. That proved critical, since most lethal toxins are bitter.

The specific appetite for sweet flavors appears to be a trait with a strong innate component among all mammals. This is a positive adaptive feature, in that sugar is a source of energy. In any case, whether more or less innate, the taste for sugary foods is reinforced in each generation thanks to the sweetness started tenderly with breast milk. Thus, human beings have always sought out sweet flavors and have progressively found a means of domesticating them, in other words, voluntarily reproducing this enjoyable taste sensation. It is likely that there are no peoples who lack a lexical means of describing the category of tastes that we call "sweet". Although the sweet taste is not unique, either in whole cultures or among members of a single culture, no society rejects sweetness as unpleasant, although some sweet things may be avoided for various reasons. Sweet flavors occupy a privileged place among salty, bitter and sour tastes. 
However, the cultural evolution regarding the demand for sugar by the human organism is paradoxical. Until the eighteenth century, sugar was a scarce, exotic luxury product. By the end of the Middle Ages, it was considered a medication and its use was extremely limited, and therefore it was sold in pharmacies. At the time of Louis XIV, sugar became a luxury genre, circulating as a present, always well regarded and accepted. In the present century, its use is restricted to a situation of overabundance. Since the nineteenth century, the uses of sugar have expanded and diversified in a parallel manner to its increased production. Consequently, it has entered the universal menu. Many dishes have become more nutritious and appetizing. Acting as a corrector of acidity and bitterness and possessing antiseptic properties, sugar became an ingredient that lent itself to all sorts of combinations, in which its taste, synonymous with sweetness, combined with pleasure (DUCROT, 2000).

Since 1900, sugar consumption has multiplied tenfold. The combination of the appetite for sugar and socioeconomic interests led to a dysfunction, a break of congruence between the appetite for sugar and the increasingly overburdened metabolic capabilities of the individual. All socio-cultural controls that may contribute to the regulation of consumption are considerably weakened by modern civilization, disintegrating and accelerating the chain reaction. (Fischer, 1979).

Sugar - whether coming from beets or sugar cane - started to be produced in specific territories around the world. Brazil, Cuba, France and Germany are the large producers, which does not mean that they are the main consumers.

Another feature that differentiates humans from the rest of the omnivorous mammals is the fact that they consume products whose taste is unpleasant to them when tried for the first few times - such as the eggplant, the guariroba (Syagrus oleracea), a bitter palm very traditional in Goiás, and for some, the aforementioned pequi. Added to the above are some of the most sought after products in the world such as pure coffee, ginger, horseradish, alcoholic drinks, hot and black peppers, all extremely irritating to the sensitive lining of the mouth.

The almost universal use of spicy peppers draws particular attention and illustrates the above comment. Pepper is a condiment used a great deal in all non-industrialized societies, although it is also present in industrialized ones. Its strong flavor is due to the presence of Capsaicin, an irritant. In any case, there are a number of reasons for its widespread use. Spicy peppers outweigh all other plants as a source of vitamin A and contain a good amount of the vitamins B and C. Eating a modest portion contributes in an important way to the balance of the diet of some tropical and subtropical societies whose vitamin intake from other sources is marginal. In addition, hot peppers have the advantage of reducing the body temperature, as Capsaicin, even in minute quantities, causes perspiration. Also, spicy peppers increase gastric secretions, stimulate the appetite, and some have aphrodisiac powers. This is why hot peppers are important in regions where basic foods are quite tasteless. Finally, there is proof that they have the power to limit the multiplication of bacteria in the organism, such as salmonellas, staphylococcus and other microorganisms known to cause intestinal disorders. In short, they have an essentially adaptive function in certain environments.

According to Ducrot (2000), pepper was the first spice used in India, and is still usedtoday. Since its introduction to Europe in the sixth century BC it has been very successful, so that it remains part of the cuisine in countries such as India, Mexico and Brazil.

The first recognizable specific mention of a spice in the Bible refers to cinnamon, which was also the first Western spice. The Greeks and Romans introduced it to their kitchens in the eighth and ninth centuries. Formerly it was used as a medicinal and aphrodisiac spice. The author quoted above (2000) tells us that Nero used his entire stock of cinnamon on the funeral pyre of the wife he had murdered, as a form of tribute. He also reports that, for centuries, the Venetians exploited the fact that the medieval kitchen could not do without its taste and smell, practicing price-fixing and becoming rich and powerful. However, in the sixteenth century, the Portuguese settled in Ceylon, where they ransacked Arab and Italian ships and conquered, with blood and terror, the control of the sale of cinnamon, which lasted about 50 years until they were expelled by the Dutch and the British. 
In addition to the symbolic and economic values attributed to certain foods, when it came to food humans enjoyed the ability to overcome their first reactions and to adapt to certain foods whose flavor initially the displeased them.

\section{THE RELATIONSHIP BETWEEN CULTURE AND NATURE OF/IN FOOD}

Despite its transcendence, biological conditioning is not sufficient to explain the alimentary behavior of the human species. As has been said, eating is a social and cultural phenomenon. According to Back (1977) apud Hernandez and Arnaiz (2005), even in our modern society food configures important aspects of socio-cultural identity. In almost all societies, eating is essentially a social activity and has already been mentioned herein. How food is prepared and served - in addition to the ways it should never be served - reveal the means through which individuals in different societies project their identities.

According to Hernández and Arnaiz (2005) three arguments serve as the basis for the idea that alimentation is a fact that transcends biology to enter the realm / dimension of culture and become food:

1) There are aversions and preferences between different cultures in relation to the same source of protein - for example, insects, frogs, snails, dogs, cows - that go beyond biological conditioning and refer to different strategies of adaptation to the environment;

2) In all known cultures, food prohibitions seem more important when it comes to animal products than when it comes to plant products. Animals have morphological attributes that make them much closer to human beings;

3) Anthropologists have observed that very often meat is the most popular food. The valuation of meat in many cultures and innumerable eras is a finding of such significance that historians measure the prosperity of a period and / or a social category by the increased per capita consumption of meat.

Therefore, it can be stated that alimentation links the natural and the social in a broad sense, and that eating serves as a means to discover how humans are both biological organisms and social beings.

In a study on planting, harvesting and eating carried out with the farmers of Mossâmedes, a municipality in the state of Goias, Carlos Rodrigues Brandão (1981) presented an interesting analysis of the farmers' perception of food and nature. These farmers distinguish between: a) what is from nature; b) what is used from nature; c) what is not fit to eat; d) what is edible.

The recognition of nature until the limits of food can be schematized as follows Figure 2.

Men do not eat wood and a vast number of plants and animals, say those farmers from Mossâmedes, although it is known that people in other places may eat animals such as guinea pigs, Tegu lizards, snakes and mice. Thus, inedible nature is inappropriate nature.

According to the same study by Brandão, a number of products obtained from nature are recognized as indigestible by the mouth and are not considered as types of food. This category includes water and medicine, and there is an intermediate category, which contains what is put "on food" such as salt and other seasonings.

Some anthropologists have presented studies showing that societies can appropriate a direct area of nature without the mediation of their work, that is, man acting as a producer. This is the case with fishing, hunting and gathering. Among the food gathered, honey bees (single animal), roots and berries stand out. In the case of Goiás, one can cite the guariroba (Syagrus oleracea), the araticum (Annona coriácea), the puruí (Alibertia edulis), the bacupari (Garcinia gardneriana), the 
jatobá (Hymenaea stigonocarpa Mart.), the ingá (Inga vera), the cagaita (EugeniIn dysenterica), the jenipapo (Genipa americana), the tarumã (Vitex polygama) and the baru (Dipteryx alata), among others in the bush. The most pleasing in nature are found on the plains and the Cerrado: Monkey Nuts (Anacardium humile), the mangaba (Hancorniaspeciosa) and the nanche (Hancornia speciosa). It is worth repeating that the most important in the local diet are pequi and guariroba.

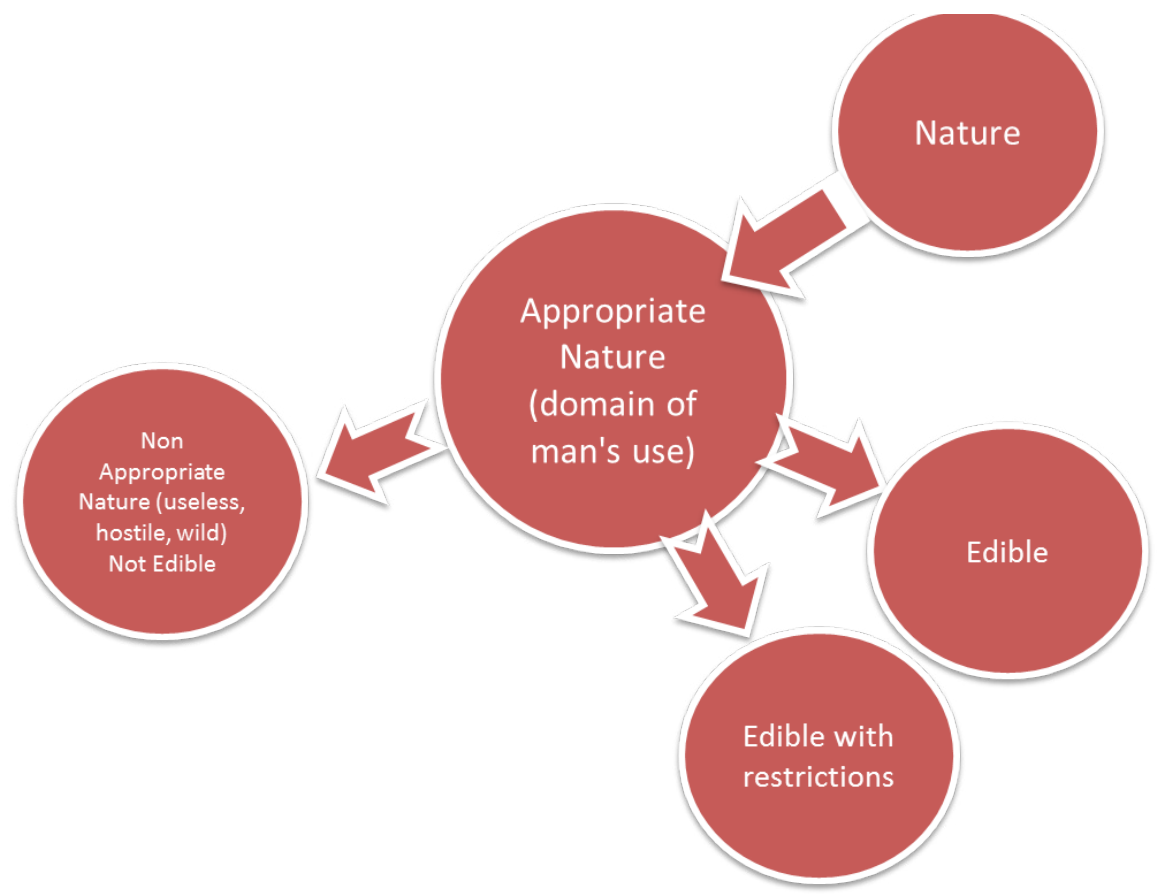

Figure 2 - The perception of nature and its relationship with foods Source: Adapted from Brandão, 1981, p.97

All food not obtained from nature, but from their own resources is derived from man's work on the farm, in the yard and backlands, or is purchased. In the field, he plants grains, some roots, and sugarcane; whereas in backyards, there are fruit trees, medicinal plants, sometimes maize, cassava and potatoes. This classification can be simplified into: city food and food from the farm, which is divided into nature, pasture, the yard, the fields (Figure 3).

It can be concluded that not everything that is potentially edible in nature can be eaten by man, because certain foods should not be eaten by certain types of people.

It is important to note, moreover, that De Certeau; Giard; Mayol (1997) remind us that food is not presented to man in natura. The food on the trees is already a cultivatedelement simply because it is considered edible. The notion of being edible is primarily cultural: grasshoppers and chapulines are eaten in Mexico. Bosintang, a dish made with cooked dog meat, is very popular in Korea and Parilla is a mixture of grilled meat and offal eaten by Uruguayans and Bolivians. In Brazil, on the island of Marajó "turu" soup is a delicacy; the main ingredient is a mollusk similar to a worm that develops in mangrove trees; in the Northeast buchada and panelada (made of bovine intestines) are popular and despite being bitter so is the guariroba in Goiás; all strange foods to those who are not accustomed to them.

\section{RETURNING TO BELIEFS AND THE SYMBOLIC VALUE OF FOODS}

Food also figures as a privileged way to reflect manifestations of symbolic thought and on occasion, as a way to symbolize reality. We create food categories: healthy and unhealthy, conve- 


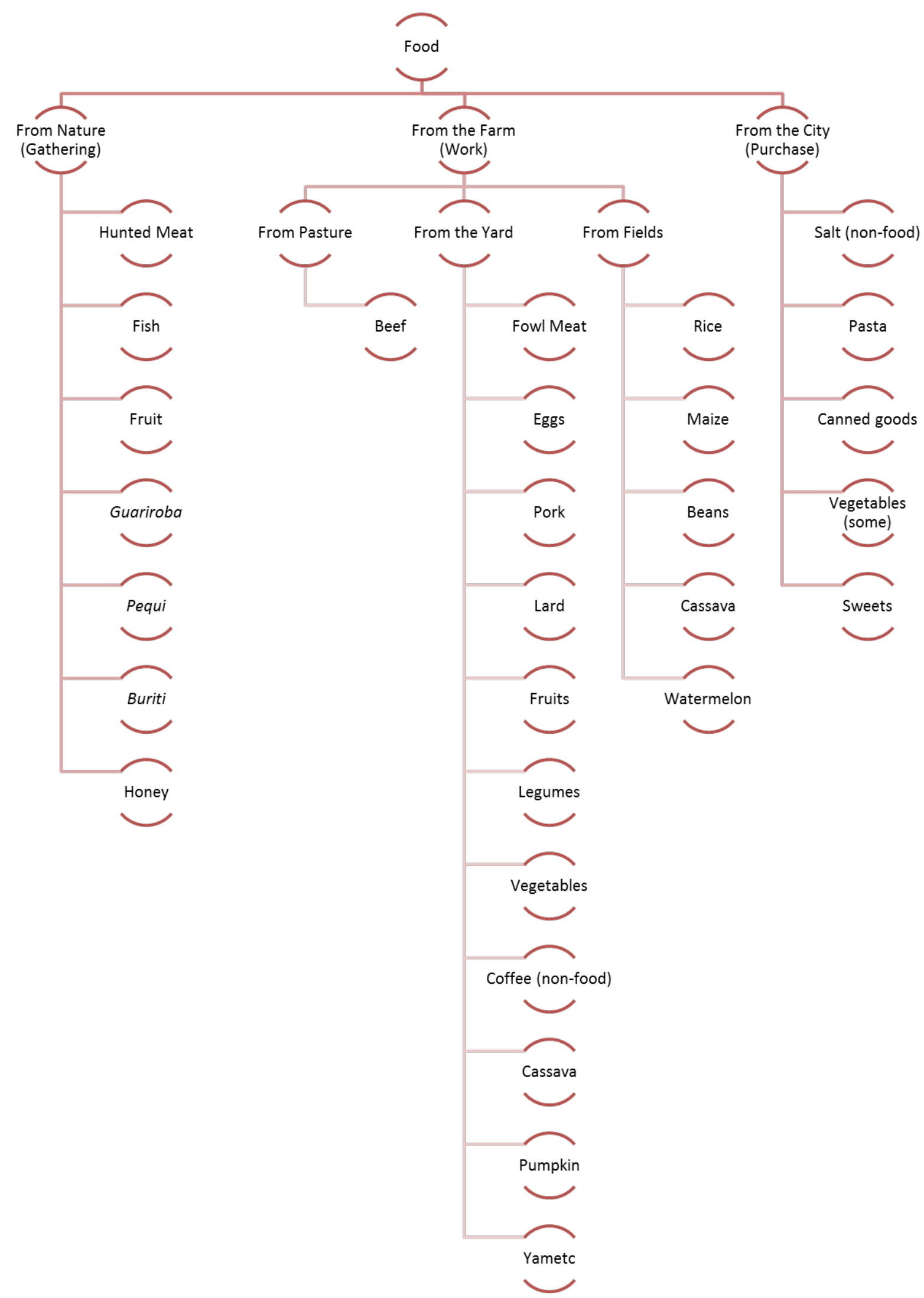

Figure 3 - Food and its origins

Source: Adapted from Brandão, 1981, p.101 
nient and inconvenient, ordinary and festive, good and bad, hot and cold, pure and impure. Using these classifications we construct the rules that govern our relationship with food and even our relationships with others, also in accordance with their different categories. Moreover, the mechanism that prevents rice and beans being served at a wedding party is the same one that normatizes serving sugar cane rum to men and liquor to women. This mechanism is guided by a system of existing beliefs and values in any culture and can determine what foods are acceptable or rejectable objects in every situation and for every type of person. At present, sugar, as reported, went from a medicine to a luxury condiment among the elite, before becoming extremely popular. In recent years, however, Saccharophobia has been growing.

In the case of meat, in the Old Testament the earthly Paradise was vegetarian. It was only after the Flood that God gave man the right to eat flesh, and since the Middle Ages the rules of Lent have ruled Catholics' alimentation, establishing days of fasting from meat. As stated above, meat is considered a virile and masculine food that is sinful and hot. Eating an animal's flesh can mean acquiring its life force.

The taboos regarding non predators share the idea that the taboo animals belong to a culturally defined world, and simultaneously contradict it. Moreover, there is a taboo if the animal resembles humans in some respect or transgresses the cultural definition of the boundaries between man and animal. In relation to other foods, meat has a very particular status and its consumption can only occur, as stated by Fischler (1995), if it is conceived as something alien to the human, as if a distinction in the quality of being animal-human, in certain circumstances, can be frayed, giving rise to a kind of continuum of the living. The consumption of meat could only be possible by breaking this continuity.

The sex-food binomial proves to be closely linked in all cultures since it represents two intertwined forms of sensuality, as Da Matta (2000) comments in a tasteful, entertaining way regarding the relationship between food and women in Brazil. We will not enter into this discussion but we recommend reading the book $\mathrm{O}$ que faz o brasil, Brasil?

This conception of foods as stimulating sensuality also refers to those called aphrodisiacs. The list is extensive in different cultures. These are foods which, when ingested, accelerate the pulse, increase blood pressure, increase body temperature and sometimes even cause a little sweating, a physiological exchange identical to that which accompanies the orgasm.

In old age, it seems that the taste buds lose sensitivity and there is need for fewer calories than in youth. In old age, it seems that the interest in aphrodisiacs is annulled and the individual focuses on a diet that extends life. In this sense, beliefs turn to different types of foods and diets that preserve health and longevity. Some people attribute their longevity to certain foods, since they preserve the best levels of health. This is the case of olive oil in the Mediterranean region, a particular yogurt in the Caucasus region and the wine in the various regions of the earth.

\section{FINAL CONSIDERATIONS}

In the words of De Certeau, Giard and Mayol (1997), is can be asserted that there is a subtle economy of options, tastes, dislikes and attractions, which form a complex geography of flavors and foods. There is an explanation for the fact that man does not feed on natural nutrients and pure dietary principles. Also, regarding cultivated foods, the authors say (1997, p.233) that how to prepare and consume the foods of each region and country reflects "a detailed picture of values, rules and symbols, around which the food model of a cultural area in a given period is organized".It is even possible to state that these foods create territories, leading to a material and immaterial geography of space. Thus this reflection reinforces the theme and its nature as an object of geographical interest.

The same authors also admit that the art of nourishing relates to the art of loving. To illustrate this statement, among the Inca and Mayan indigenous peoples it is still traditional to bury the dead 
with music and banquets and on the day of the dead, to take an offering of the deceased's favorite dishes to their tomb. In this case the demonstration of love is also linked with death. Even today, at wakes in France, after the burial the family begins mourning with a meal for the occasion, sharing food and generally even serving the wine appreciated by the deceased.

Food is essential to people's physical survival and psychological well-being but it is undoubtedly important for the social reproduction of societies - even if it is a bottle of wine, a pot of sweets, a coffee, offered as a sign of friendship, gratitude or even self-interest. Thus, through food, the emphasis is on food's social role in the manifestation of feelings that contribute to socialize individuals as members of their community. In this case, its main function is to assist in the maintenance of the social structure and therefore the system, so that its value is more social than nutritional. It is also symbolic.

This text began a reflection, supported by an ethnogeography which offers a reading for those who wish to deepen their understanding of how men perceive and exploit nature for their survival.

It is hoped that its contents encourage the reader to consider the sense of taste as a means of awareness and knowledge of nature, as well as reflecting on the cultural meanings of what and how we eat and makes us diverse and plural, people with a unique food identity.

\section{ACKNOWLEDGEMENT}

Essay associated to the Project Territorial identities and territorial/natural developmental politics at Reserva da Biosfera Cerrado - Goiás. CNPq research fellow PQ and project Nature, woman and citizenship at the traditional communities of the citizenship territory of Vão do Paranã and the RVS Veredas do Oeste Baiano. MCTI/CNPQ/MEC/CAPES grant $n^{\circ}$ 22/2014 - HUMAN, SOCIAL AND APPLIED SOCIAL SCIENCES.

\section{BIBLIOGRAPHIC REFERENCES}

ABDALA, M.C. Receita de mineiridade: a cozinha e a construção da imagem do mineiro. Uberlândia: UDUFU, 1997.

BARBOSA. R.R. Sabores e sentidos: a gastronomia no contex to da geografia cultural. In ALMEIDA, M.G, CHAVEIRO, E.F. BRAGA, H.C. Geografia e cultura. Os lugares da vida e a vida dos lugares. Goiânia: Ed. Vieira, 2008, 204-221.

BRANDÃO, C.R. Plantar, colher, comer. Rio de Janeiro: Ed. Graal, 1981.

CASTRO, J. Ensaios de Geografia Humana. Porto: Ed. Brasília, 1976.

CLAVAL, P. Géographie Culturelle.Une nouvelle approche des sociétés et des milieux. Paris. 2eme édition.Armand Collin, 2012.

CLAVAL, P. A Geografia Cultural. Florianópolis: Ed. UFSC, 1995.

COELHO, V.P. A festa do pequi e o zunidor entre os índios Waurá. Scheizerische Amerikanisten Gescllschaft. Bull. 55-56, 1991-1992.

DA MATTA, R. O que faz o brasil Brasil? Rio de Janeiro: Rocco, 2000.

DE CERTEAU, M; GIARD, L, MAYOL, P. A invenção do cotidiano. 2. Morar, cozinhar. Petrópolis: Ed. Vozes, 1997.

DUCROT, V, E. Los sabores de la historia. Los grandes acontecimientos de la humanidad contados desde la mesa y la cocina. Buenos Aires: Grupo Editorial Norma, 2000.

FISCHLER, C. Gastro-nomía y gastro-anomía: sabiduría del cuerpo y crisis biocultural de la alimentacion contemporánea. In: CONTRERAS, J. (Comp.). Alimentación y cultura: necesidades gustos y costumbres, 1995, p. 357-380. 
HERNANDEZ, J, C., ARNÁIZ, M.G. Alimentación y cultura. Perspectivas antropológicas. Barcelona: Ariel, 2005.

LEVI-STRAUSS, C. O cru e o cozido: Mitológicas I São Paulo: Cosac Naify. 2004/1964.

PITTE, J.R. Gastronomie française. Histoire et géographie d'une passion. Paris: Fayard, 1991.

PITTE, J.R. Terres de Castanide. Hommes et paysages du châtaigner en Europe de l'Antiquité à nos jours. Paris: Fayard, 1981.

SHALINS, M. Au Coeur des societés. Raison utilitaire et raison culturelle. Paris: Gallimard., 1988.

THOMAS, K. O homem e o mundo natural. São Paulo: Companhia das Letras, 1988. 